\title{
Middle Palaeolithic flint procurement in Central Mediterranean Iberia: Implications for human mobility
}

\author{
Aleix Eixea ${ }^{1}$, Clodoaldo Roldán ${ }^{2}$, Valentín Villaverde ${ }^{1}$ and João Zilhão ${ }^{3}$ \\ 1. Departament de Prehistòria i Arqueologia, Universitat de Valencia. Blasco Ibáñez, 2846010 Valencia, Spain. \\ Email: Eixea: alejo.eixea@uv.es; Villaverde: valentin.villaverde@uv.es \\ 2. Instituto de Ciencia de los Materiales, Universitat de Valencia (ICMUV). Parc Cientific. C/ Catedrático José \\ Beltrán, 246980 Paterna, Valencia, Spain. Email: clodoaldo.roldan@uv.es \\ 3. Departament de Prehistòria, Història Antiga i Arqueologia. Universitat de Barcelona/ICREA, Barcelona, \\ Spain. Email: joao.zilhao@ub.edu
}

\begin{abstract}
:
Different flint types from the Middle Palaeolithic site of Abrigo de la Quebrada (Chelva, Valencia) are characterized, both macro- and microscopically, and compared with types found at other localities in the region. Although procurement predominantly concerned the immediate vicinity of sites, our results show the presence of the same types in assemblages separated by distances of up to $120 \mathrm{~km}$. The long distances involved are suggestive of a pattern of North-South mobility of human groups along the coastline of central Mediterranean Iberia.
\end{abstract}

Keywords: x-ray fluorescence; x-ray diffraction; raw materials; Middle Palaeolithic; Valencian country

\section{Introduction}

The information available for the Valencia region on prehistoric raw material sources and procurement is scant. Systematic studies have been carried out over limited areas only, and geological mapping of the distribution of the siliceous variants used is non-existent. The available data pertain mostly to the Alicante province, and derive, namely, from studies by: (a) Menargues (2005), on finds from Ratlla del Bubo and Cova de les Cendres; (b) García Carrillo (García-Carrillo et al. 1991), on finds from Tossal de la Roca; (c) Faus (2008-2009), on the outcrops of siliceous raw materials in the Comtat and Marina Alta areas; (d) Schmich \& Wilkens (2006), on the precise characterization by PIXE analysis (Proton Induced X-ray Emission) of outcrops related to the Polop Alto sites; and (e) Molina et al. (2010) on the Abric del Pastor (Alcoi, Alicante). As far as the Valencia province is concerned, research has been limited to isolated classification of finds from the sites of Parpalló (Tiffagom 2006) and Cova Negra (Moriel 1985) deposited in museum collections (Figure 1).

This lack of information is particularly problematic in the case of the region's Middle Palaeolithic, and limits attempts at establishing a framework for the discussion of patterns of

Published by the School of History, Classics and Archaeology, University of Edinburgh ISSN: 2055-0472. URL: http://journals.ed.ac.uk/lithicstudies/

This work is licensed under a Creative Commons Attribution 2.5 UK: Scotland License. 
human mobility during this period. Recently, however, analysis of the raw materials used at Abrigo de la Quebrada (Eixea et al. 2011), located in an area so far unstudied, allowed some interesting insights. Here, using both macro- and microscopic analyses, we compare the types of raw material used at Quebrada with those used at other Valencian sites.

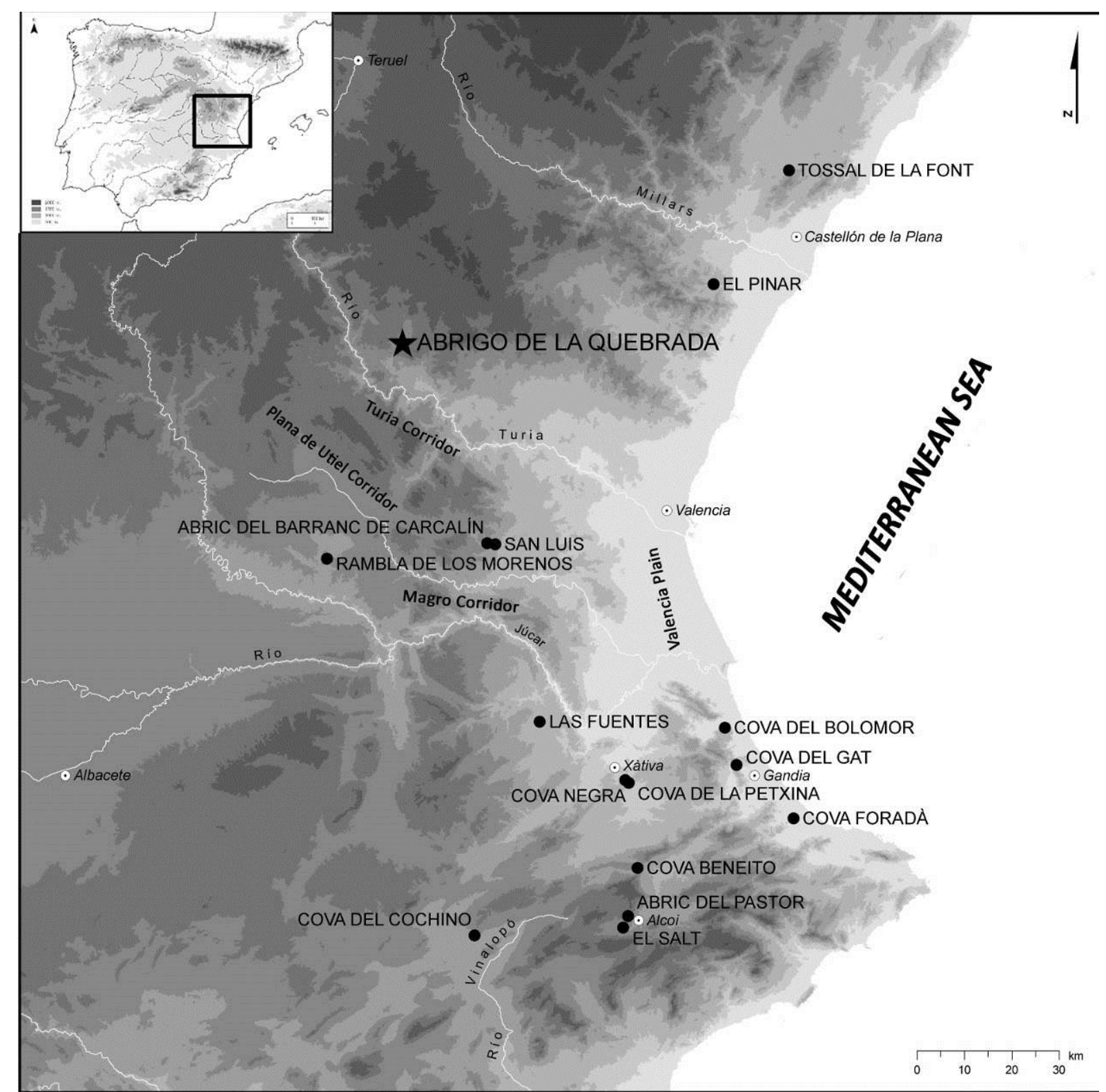

Figure 1. Map of sites referred to in the text.

\section{The Abrigo de la Quebrada}

The Abrigo de la Quebrada (Quebrada rock-shelter; henceforth, Quebrada) is located near Chelva (Los Serranos), some $65 \mathrm{~km}$ northwest of the city of Valencia. The area's main geographic features are the Tuéjar-Chelva and Turia rivers and the rather steep mountains of the Javalambre and Sierra de Utiel massifs of the Iberian Range that they drain (Figure 2).

The site is located on the left bank of the Barranco de Ahillas ravine. Defined on the basis of the present day position of the overhang and the extent of the horizontal platform it protects, the rock-shelter is $38 \mathrm{~m}$-long and between 2 and $9 \mathrm{~m}$-deep. The floor surface is rather flat, with a slight dip from North to South. As it is oriented to the North-West and is inset in a very narrow and steep ravine, the site receives little direct sunlight. 


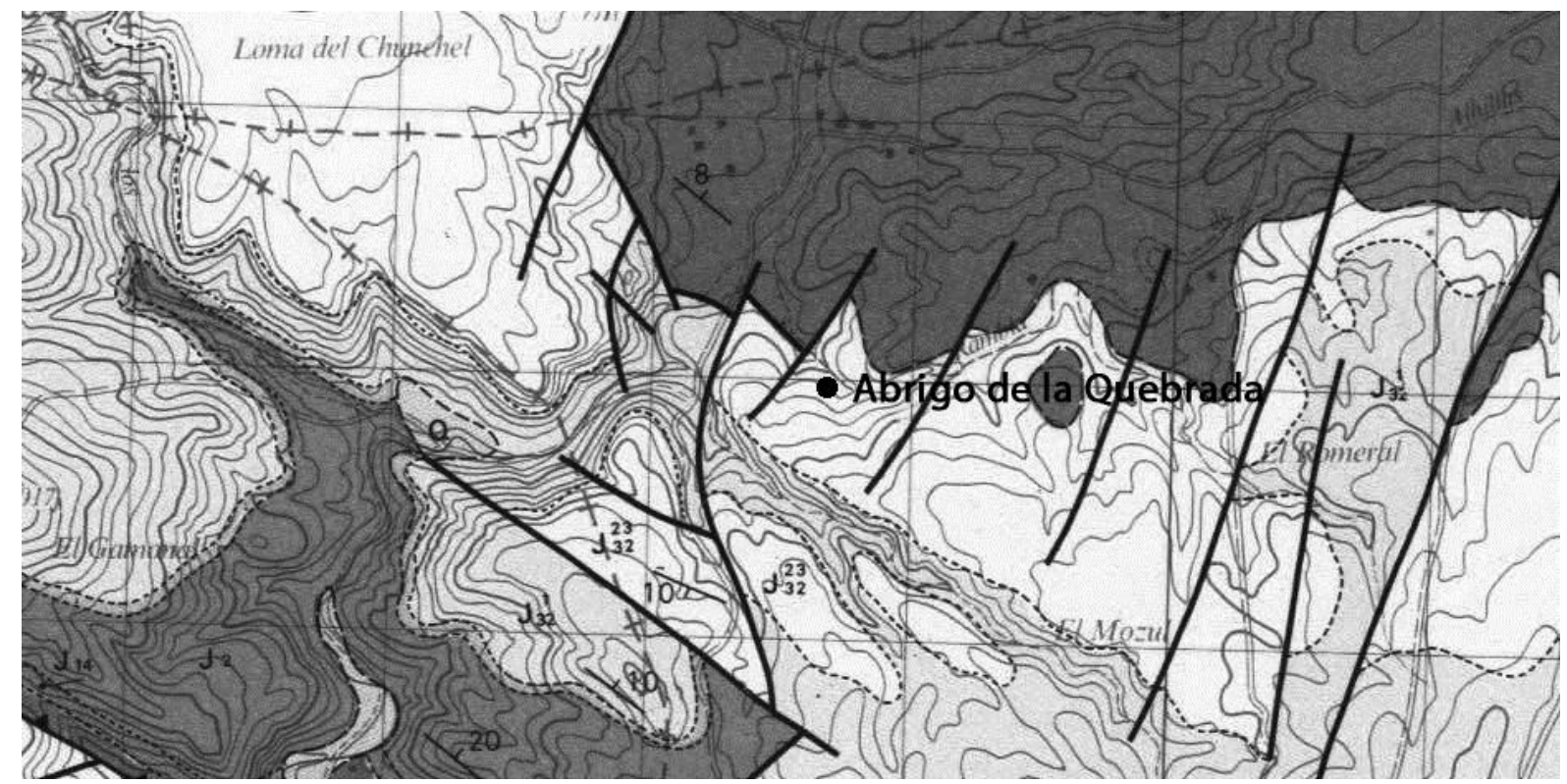

Figure 2. The geological setting of Quebrada, according to sheet 666, 27-26 (Chelva) of the 1:50.000 Geological Map of Spain (IGME 1972). J23-32 (Jurassic Malm Upper Kimmeridgian), J1-32 (Jurassic Malm Lower Kimmeridgian) and O (Ordovician).

In geological terms, the area belongs to the Iberian Range (Cordillera Ibérica) geological unit, which belongs to the Upper Jurassic complex (Kimmeridgian) and features the deposition of pisolitic and oolitic limestone in a neritic to coastal, 30 to $40 \mathrm{~m}$ deep water. The fact that this section is generally micritic and only occasionally, on the upper part, sparitic, indicates a mid-energy environment where pisoid formation is explained by pressure from algae in a carbonate-rich basin. The upper part of the Kimmeridgian reflects a higher energy environment, given the sparitic matrix and the presence of intraclasts and oolites. In palaeogeographic terms, this Jurassic complex lies within the Iberian facies domain (dominio de facies ibérica). More specifically, it is located at the boundary between the Iberian and the Prebaetic facies; some authors (IGME 1972) have used the "Betiberian facies" (facies betibéricas) expression to refer to this boundary.

The Abrigo de la Quebrada stratigraphy features a total of eight units distributed over a thickness of some $3 \mathrm{~m}$. The base of the sequence has not yet been reached. Level 1 is a disturbed unit resulting from use of the rock-shelter as a sheep pen in recent times. Below, levels 2 through 5, 7 and 8 show evidence of human occupation. Level 6, almost $1 \mathrm{~m}$-thick, is sterile. All the occupations feature Middle Palaeolithic stone tool assemblages. The richest are those in levels 3, 4 and 5. The following AMS dates on charcoal have been obtained: for level 3, 40,500 \pm 530 BP (Beta-244003), on a sample of Pinus nigra recovered in spit 5 of square B5; for level 4, 43,930 $\pm 750 \mathrm{BP}$ (Beta-244002) on an ABA-treated sample of Pinus cf. pinaster from a combustion feature in spit 6 of square A4, and >50.8 ka BP (OxA-24855) on a ABOx-ed sample of Pinus cf. nigra (Villaverde et al. 2008; Eixea et al. 2011-2012).

\section{Methods}

Our main objective was to provide a petrographic context for the Quebrada artifacts. In order to allow a provenience study of the highest possible resolution, they were compared to a reference collection of geological raw materials located in the immediate vicinity, assembled on the basis of a systematic survey. This survey covered an area of some $400 \mathrm{~km}^{2}$ around the site, although potential sources up to $60 \mathrm{~km}$ away were also visited. We followed the habitual 
protocol: analysis of geological maps, assessment of toponymic information, and questioning of local informants. We also ran a few 2-3 km-long transects where raw material and encasing rock formations were systematically recorded, photographed and collected. The located outcrops feature the raw material variants making up the archaeological assemblages for the most part. Even though also found farther away, all such variants, namely the Domeño-type flint (see below), could be documented at $<10 \mathrm{~km}$ from the site. In the near future we plan to refine this "local," umbrella classification on the basis of detailed mineralogical, petrological and hydrological analyses aiming at a better understanding of lithological heterogeneity within and between sources.

Macroscopic analysis (Masson 1979, 1981) was carried out with a binocular microscope under 20x or 40x magnification and used Munsell and Pantone tables. Color, texture, impurities and cortex features were recorded.

In addition, we obtained chemical data for 46 Quebrada-related samples, of which 41 were archaeological finds and five were from the regional outcrops located during the survey work. Comparative data for the assessment of the provenience of the site's allochthonous flints were obtained through the analysis of an additional set of nine samples. Six were artefact samples from sites located in the southern part of the study area - Middle Palaeolithic Cova Negra (Xátiva, Valencia) and Upper Palaeolithic Cova de les Cendres (Moraira, Alicante) (Villaverde 1984; Villaverde et al. 2010). The other three samples were from natural flint outcrops - Serreta-type (Alicante) (Molina et al. 2010) and Mora de Rubielos (Teruel) - located to both the North and the South of the study region and that are known to have been widely used throughout the Palaeolithic of Valencia. (See Table 1.)

Table 1. Samples analyzed in this study.

\begin{tabular}{lccc}
\hline Sample type & $\begin{array}{c}\text { Sample type } \\
\text { code }\end{array}$ & $\begin{array}{c}\text { Number of } \\
\text { samples }\end{array}$ & Source \\
\hline Allochthonous Type 1 (archaeological) & A1 & 5 & Abrigo de la Quebrada \\
Allochthonous Type 2 (archaeological) & A2 & 9 & Abrigo de la Quebrada \\
Allochthonous Type 3 (archaeological) & A3 & 8 & Abrigo de la Quebrada \\
Allochthonous Type 4 (archaeological) & A4 & 5 & Abrigo de la Quebrada \\
Geological & M & 5 & Chelva quarries \\
Archaeological & CN & 2 & Cova Negra \\
Archaeological & CC & 4 & Cova de les Cendres \\
Geological & UV1 & 1 & Penella (Alicante) \\
Geological & UV2 & 1 & Beniaia (Alicante) \\
Geological & UV3 & 1 & Mora de Rubielos (Teruel) \\
\hline
\end{tabular}

All samples were analyzed in non-destructive mode by means of energy dispersive X-ray fluorescence spectrometry (EDXRF). A selected set of artefact samples (chippage or debris) was ground and the resulting powder was analyzed by X-ray diffraction spectrometry (XRD). All measurements were performed at the Archaeometry Unit of the Materials Science Institute, University of Valencia (ICMUV). In order to obtain better petrographic information, thin sections of these samples are currently being processed. The results of their forthcoming analysis are expected to improve the lithological information obtained so far.

EDXRF analysis was performed using a portable spectrometer equipped with a silver transmission target X-ray tube (40 kV/50 A, maximum) and a Peltier cooled Si-PIN detector with a resolution of $165 \mathrm{eV}$ (FWHM @5.9 keV). An aluminium collimator reduces the X-ray beam to a 3-5 mm diameter spot size. The X-ray beam impinges perpendicular to the sample and the excited fluorescence radiation of the sample is recorded by the detector under $45^{\circ}$ 
geometry. The spectrometer was operated at $30 \mathrm{kV}$ and $4 \mu \mathrm{A}$ with an acquisition time of 180 live seconds. The minimum detection levels for the spectrometer in terms of \%-weight are: about $2-3 \%$ for $\mathrm{Si}$ and about $0.1 \%$ for elements with $\mathrm{Z}$ between $\mathrm{Z}=18$ and $\mathrm{Z}=30$. All archaeological and quarry samples were left untreated except for cleaning with demineralized water prior to analysis.

Only one EDXRF analysis was performed for each sample. Therefore, and considering the raw materials' heterogeneous composition, the results presented here should be considered preliminary. Previous analyses have shown that results can vary within a single sample depending on the measurement spot, because of heterogeneity in composition. Thus, in order to increase the resolution and statistical power of the analysis, a larger number of measurements per sample will be carried out in future stages of the project.

The EDXRF spectra of the analyzed samples indicate that the identified elements are $\mathrm{Si}$, $\mathrm{P}, \mathrm{S}, \mathrm{Cl}, \mathrm{Ca}, \mathrm{Ti}, \mathrm{Mn}$ and $\mathrm{Fe}$, with $\mathrm{Si}, \mathrm{K}, \mathrm{Ca}$ and $\mathrm{Fe}$ as the elements showing higher fluorescence line intensity. The heterogeneity of the samples is high, especially in regard to the presence of calcium; even on the same sample, the net areas of this element show, extreme variability caused by the heterogeneous presence of calcium minerals. These observations highlight the limitations of non-destructive EDXRF analyses in relation to e.g. sample homogeneity, mineralogy or surface irregularity.

XRD analysis was performed using a Bruker D8-Advance diffraction system operating at $40 \mathrm{kV}$ and $30 \mathrm{~mA}$ with a $\mathrm{Cu}$ anode. The intensity was measured in the range from $5^{\circ}$ to $80^{\circ} 2 \theta$ at a step size of $0.02^{\circ}$ and a counting time of $0.2 \mathrm{~s}$. per step. Prior to measurement, the samples were powered in an agate mortar.

\section{Results}

\subsection{Macroscopically defined flint types}

Four different lithological types have so far been identified among the Quebrada raw materials: flint, limestone, quartzite and quartz. Flint is the most abundant raw material in all levels, followed in smaller percentages by limestone and quartzite; quartz is sporadic (Table 2).

Table 2. Raw materials used in levels 2, 3 and 4 of Quebrada.

\begin{tabular}{lcccc}
\hline & Flint & Limestone & Quartzite & Quart \\
\hline Level II & $75.20 \%$ & $12.80 \%$ & $12 \%$ & 0 \\
\hline Level III & $70.10 \%$ & $15.10 \%$ & $14.30 \%$ & $0.50 \%$ \\
\hline Level IV & $55.25 \%$ & $20.49 \%$ & $24.20 \%$ & $0.06 \%$ \\
\hline
\end{tabular}

The local flint type (from 5 to $8 \mathrm{~km}$ around the site) is the most abundant. Its stratotype is located on the slopes of the Turia River, close to the ruined village of Domeño. We have called it "Domeño-type flint" (sílex tipo Domeño) (Villaverde et al. 2008) (Figure 3). The coordinates of the type section on the geological map (sheet no. 27-26 (666), Chelva) are lat. $39.805622^{\circ}$ and long. $-1011372^{\circ}$ (Gómez \& Fernández 2004). This flint occurs in formations belonging to the Middle Jurassic (Dogger) of the Iberian Range, embedded within blocks of microcrystalline limestone; despite the common geological origin, it presents considerable variability in internal color. It is fine-grained and shiny, and of good knapping quality. The surface is smooth, without inclusions, opaque, with a microcrystalline texture. The base color is grey, with shades of dark green distributed smoothly and homogenously. The external appearance is semi-coarse, with brown and orangey tones. It also occurs as $15-20 \mathrm{~cm}$ irregular nodules incrusted in limestone blocks, featuring different morphologies (longish, globular, etc.) and a rather thin cortex. 

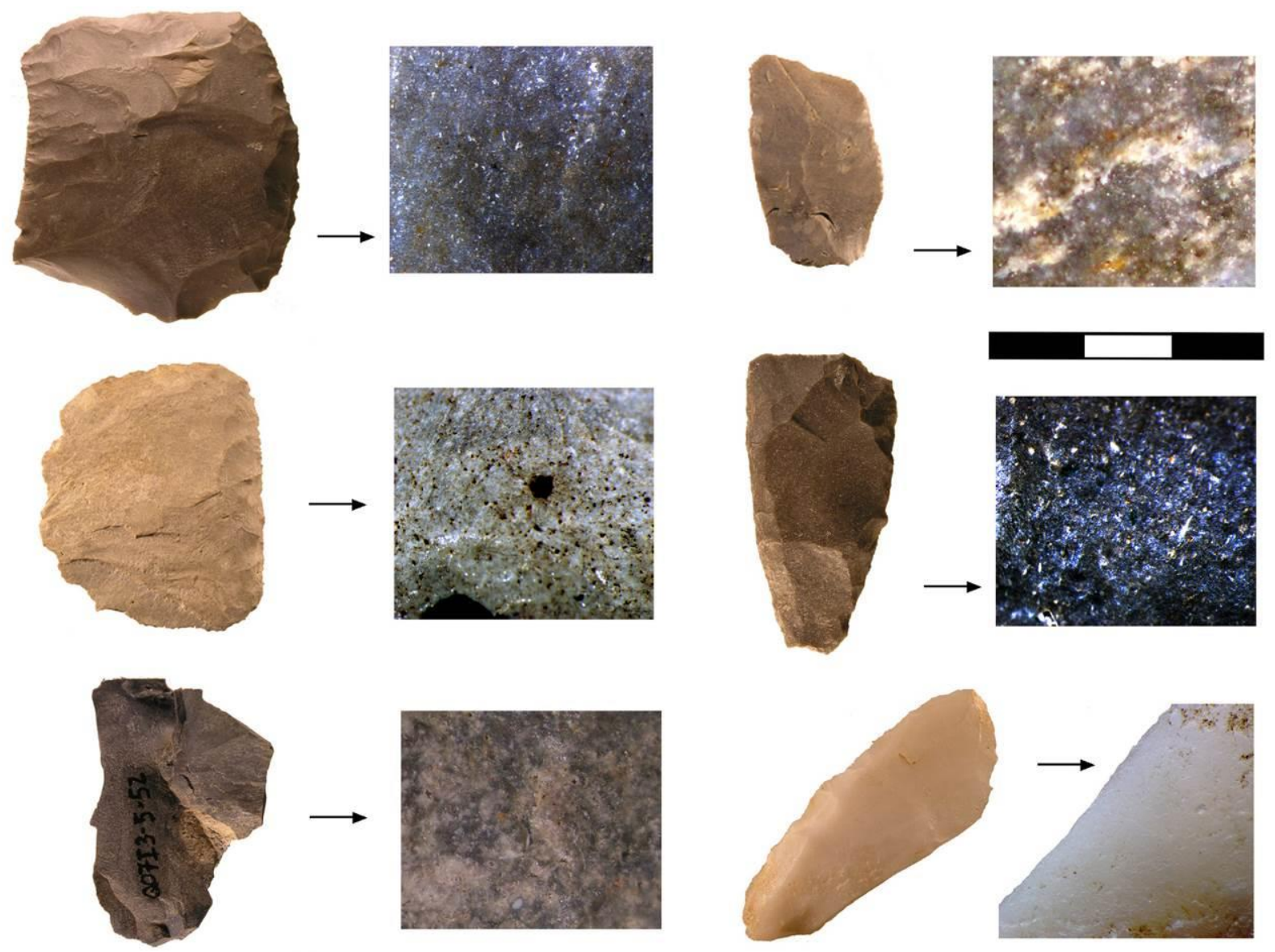

Figure 3. The locally available Domeño-type flint and its variants.

Going into more detail, this flint is characterized by the presence of mosaics of detrital macroquartz and of a large number of inclusions, with sub-types and variants being found together in a single outcrop. The non-siliceous components include iron oxides (hematite), dispersed or grouped, and other relict minerals, as well as calcium carbonate formed prior to silicification. The presence of triaxon sponge spicules and microforaminifera indicates a marine formation environment. A process of phased silicification is documented: at first fibrous quartz is generated, and then macroquartz grains are formed.

Our survey identified a series of outcrops in the vicinity of the site (Eixea et al. 2011), namely, El Collado de las Granzas, Corrales de Silla and El Mozul (Figure 4). Both morphologies (nodules and beds), indistinctly combined, are present in these outcrops, all of which are in primary position: on one hand, we have 25 to $30 \mathrm{~cm}$-thick, $>30 \mathrm{~m}$-long incrusted subhorizontal strata exposed along the slopes; on the other, we have nodules with a semicoarse cortex indicative of little rounding that remain incrusted in the encasing calcareous rock but can also be found loose on the ground. These outcrops are easily accessible, detached nodules can be found a few meters away from the primary outcrop, and the material is altogether plentiful. The abundance of material of good quality for knapping in outcrops located in the vicinity of the site indicates that the Quebrada flints were mostly procured from such sources.

Regarding the allochthonous flints, four groups have been defined so far (Figure 5). For the moment, their differentiation relies entirely on macroscopic observation (Masson 1979, 1981). Type 1 is a whitish chert with brownish and yellowish tones. The study of its cortex indicates continental formation in an evaporitic sedimentary basin, probably of Tertiary age. 
This chert is fine-grained and translucent. Among the inclusions, some - acicular pseudomorphs (gypsum crystals), iron oxide cryptograins and some anhydritic components indicate chert formation environments with high salinity levels. Two variants can be discriminated within this type: one featuring more reddish colors, due to the fact that hematite or iron oxide grains are more abundant; and another, featuring a mudstone texture, relicts of the original carbonate, and macroquartz particles, which give it a brownish color. The source of both variants remains unknown.

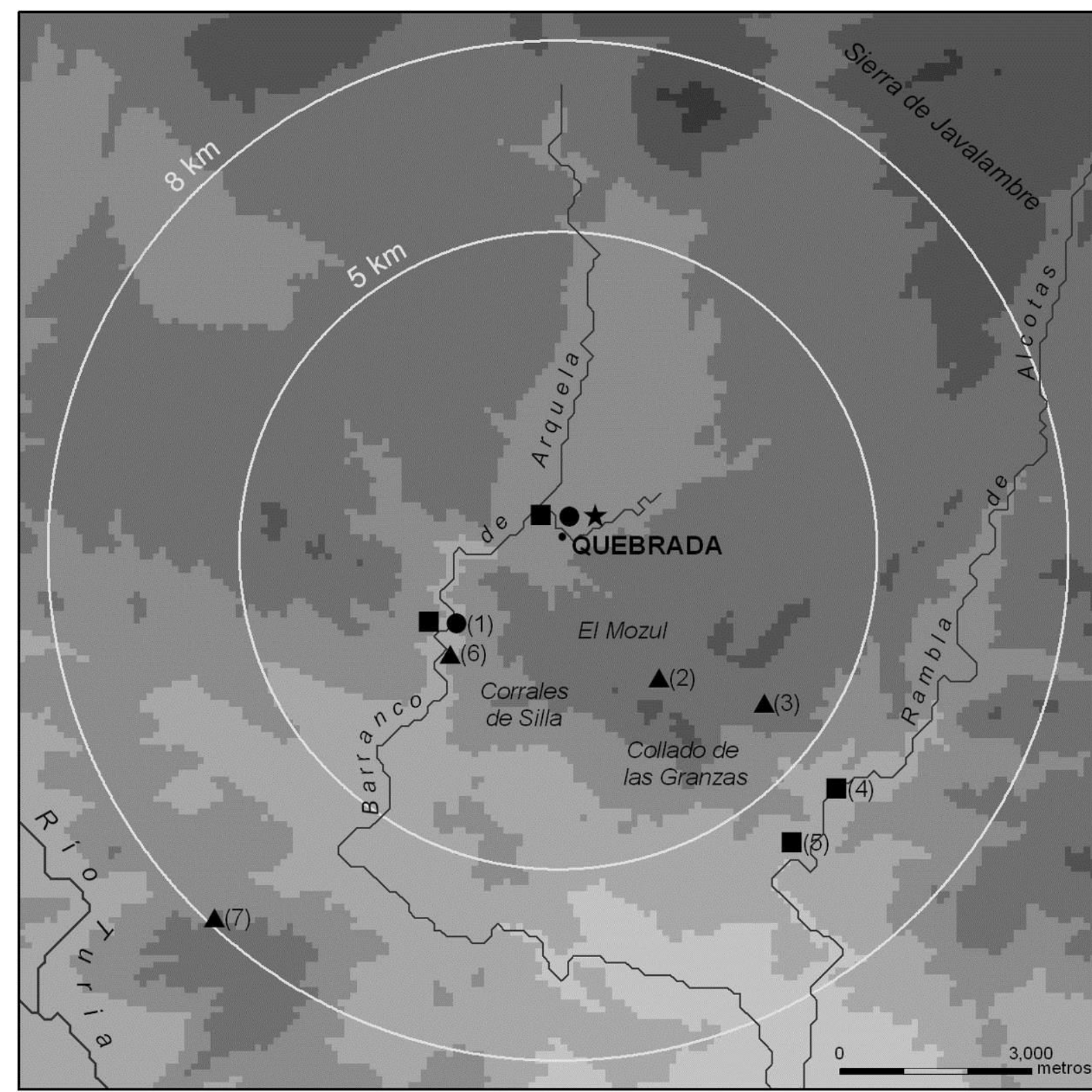

- Limestone $\quad$ Quartzite Quartz

$\Delta$ Flint

(1) Arquela

(2) El Mozul

(3) Piteras

(6) Corrales de Silla

(5) Camino Viejo de Calles-Higueruelas
(4) Alcotas

(7) Carretera CV-390 km 9

Figure 4. Procurement territories for the Domeño-type flint and other Quebrada raw materials.

Type 2 is fine-grained, with a smooth surface and microcrystalline structure, and is also of good knapping quality. Its color is light brown with small dark speckles. Internally, spicule sections, inertites and the presence of microforaminifera indicate a marine formation 
environment, probably of Cretaceous age. As with Type 1, variants can be discriminated, in this case on the basis of a lower or higher degree of silicification. An interesting point is that some flints show remains of whitish patinas as well as of a fine, smooth cortex; these features suggest that the sources correspond to tabular siliceous formations that remain to be located.
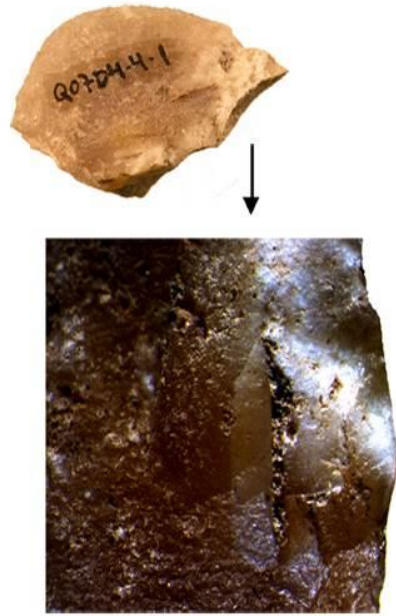

1

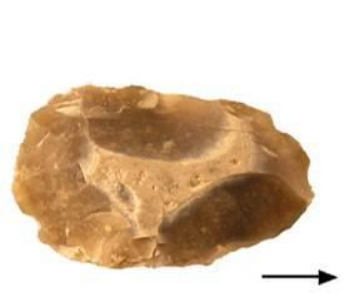

2

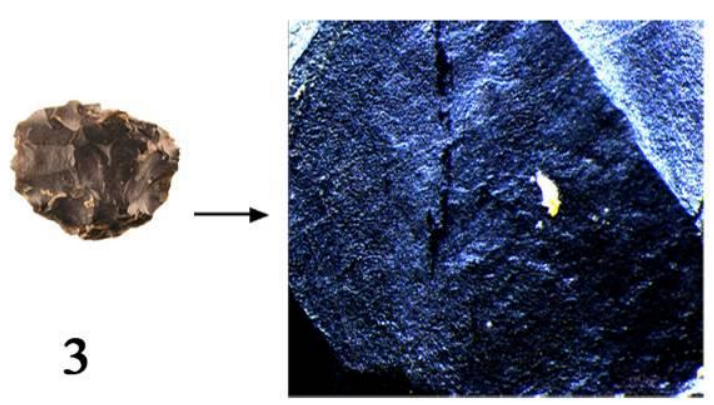

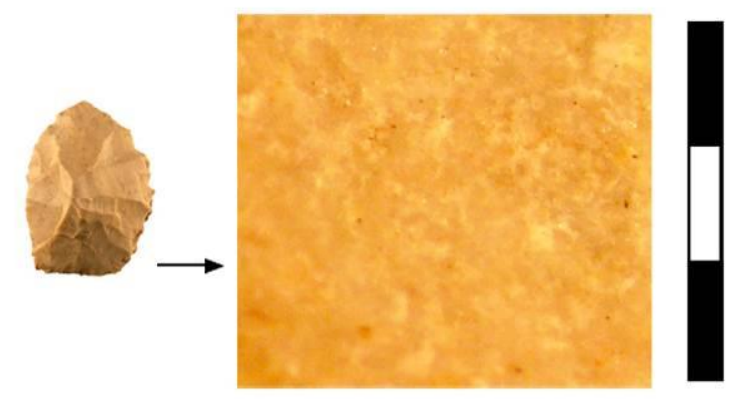

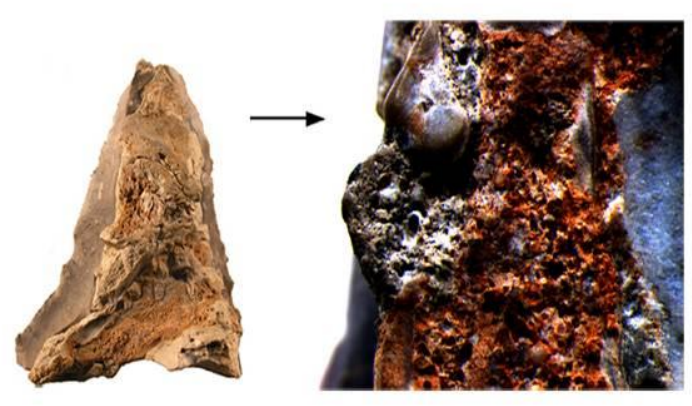

Figure 5. Allochthonous flints from Quebrada.

Type 3 is mainly characterized by its blackish color. It is also fine-grained, with a smooth surface and microcrystalline structure, and good for knapping. The presence of intraclasts of biogenic origin, along with algae remains and sea urchin spicules, suggests a marine origin for this type.

Type 4 remains incompletely characterized, but doesn't fit into any of the former. Its recognition as a separate group is corroborated by the microscopic analyses (see below). 


\subsection{Chemical and mineralogical analyses}

Principal Component Analysis (PCA) was used as a clustering data reduction technique from the normalized net areas of the major elements identified by EDXRF ( $\mathrm{Si}, \mathrm{K}, \mathrm{Ca}$ and $\mathrm{Fe}$ ). PCA uses the principal components method of extraction, analyzing the correlation matrix of rotated factors. Based on these data, diagrams showing the principal components were drawn for comparison between the local, internally variable flint samples, and the allochthonous flints (Figures 6 and 7).

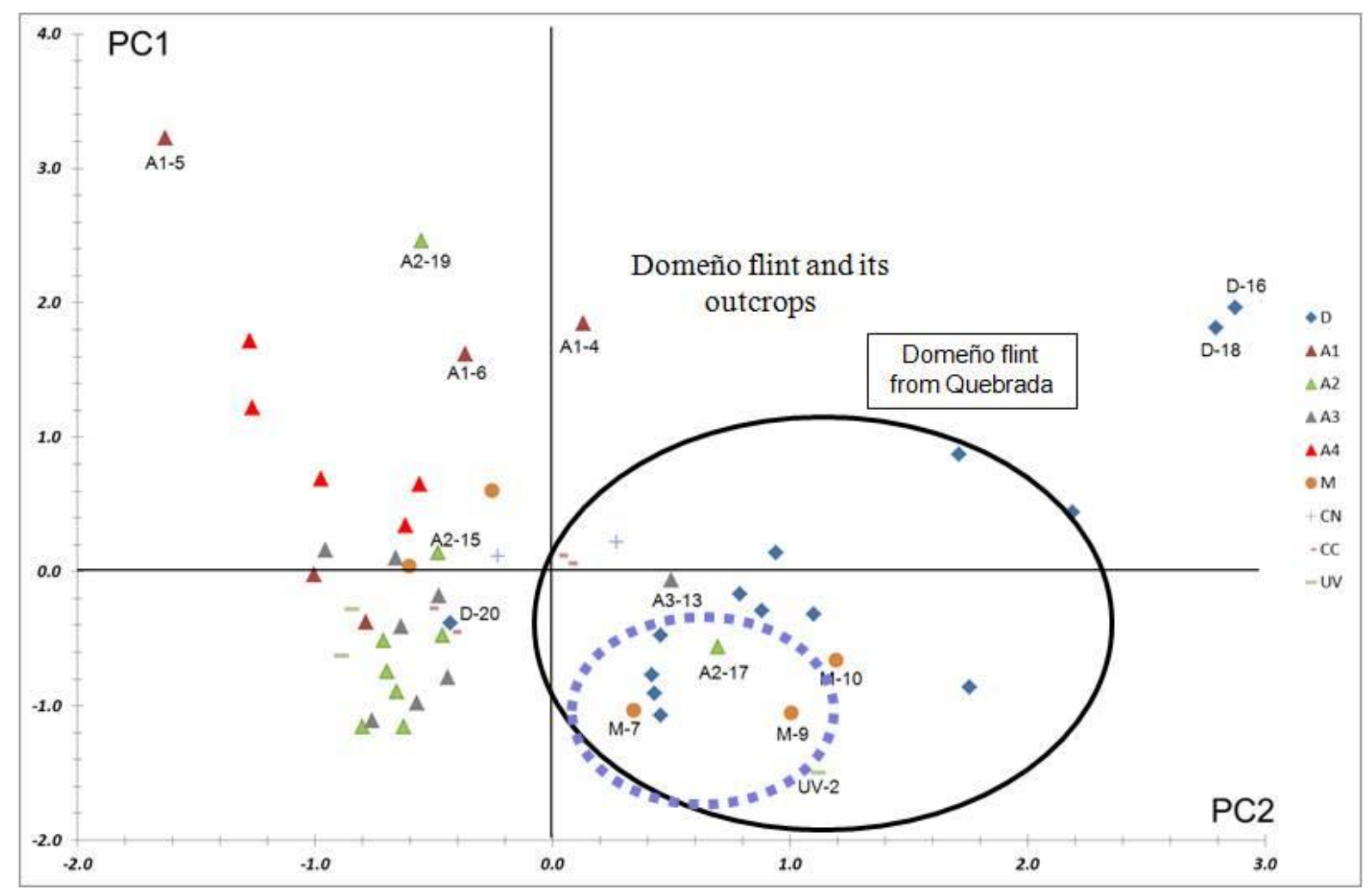

Figure 6. Principal components 1 and 2 derived from PCA analysis of the Domeño flint and its outcrops (XRF data).

Principal component 2 (PC2) is highly correlated (positive correlation) with Fe and to a lesser extent with $\mathrm{K}$, while $\mathrm{PC} 1$ has a positive correlation with $\mathrm{Ca}$ and negative correlation with Si. The Quebrada samples macroscopically catalogued as local (labelled D) cluster separately in this projection (PC2>0 in Figure 6), except for: (a) the D20 sample, which clusters with two allochthonous types, Type 2 (labelled A2) and Type 3 (labelled A3), and whose EDXRF spectrum presents a low intensity of the fluorescence peak of iron $(\mathrm{PC} 2<0)$; and (b) the D16 and D18 outliers, which, in contrast, have EDXRF spectra with intense iron fluorescence lines. The Quebrada samples of Type 2 and Type 3 present similarities (PC1<0 and $\mathrm{PC} 2<0$ in Figure 6) but do not cluster together; two of them project away from those quadrants - A2-17, which is close to the Quebrada local flints, and A2-19, which features a high intensity of the calcium fluorescence line. The Type 4 samples (labelled A4) form a separate group with values of $\mathrm{PC} 1>0$ and $\mathrm{PC} 2<0$ (Figure 6). Finally, the Type 1 samples (labelled A1) appear close to Type 2 and Type 3 (in two cases) or to Type 4 (in three cases); the A1-5 outlier presents very intense calcium fluorescence lines. Among the geologically local samples (labelled M), M7, M9 and M10 present similarities and cluster with the Domeño-type archaeological samples, while M6 and M8 are closer to Type 4 and to Type 2 or 3 , respectively. 
The macroscopic assessment and the microscopic analyses confirm the homogeneity of the Domeño-type flint. As illustrated by Figure 6, artefact samples in this raw material are quite distinct from those made on allochthonous flints while being closely related to samples from this type taken from the local outcrops. This confirms our working hypothesis that this type of flint is of local origin and was procured within a radius of between 5 and $8 \mathrm{~km}$ from the site. The outlier situation of samples D-16, D-18 and D-20 may be due to analytical issues associated with surface alterations or sampling error.

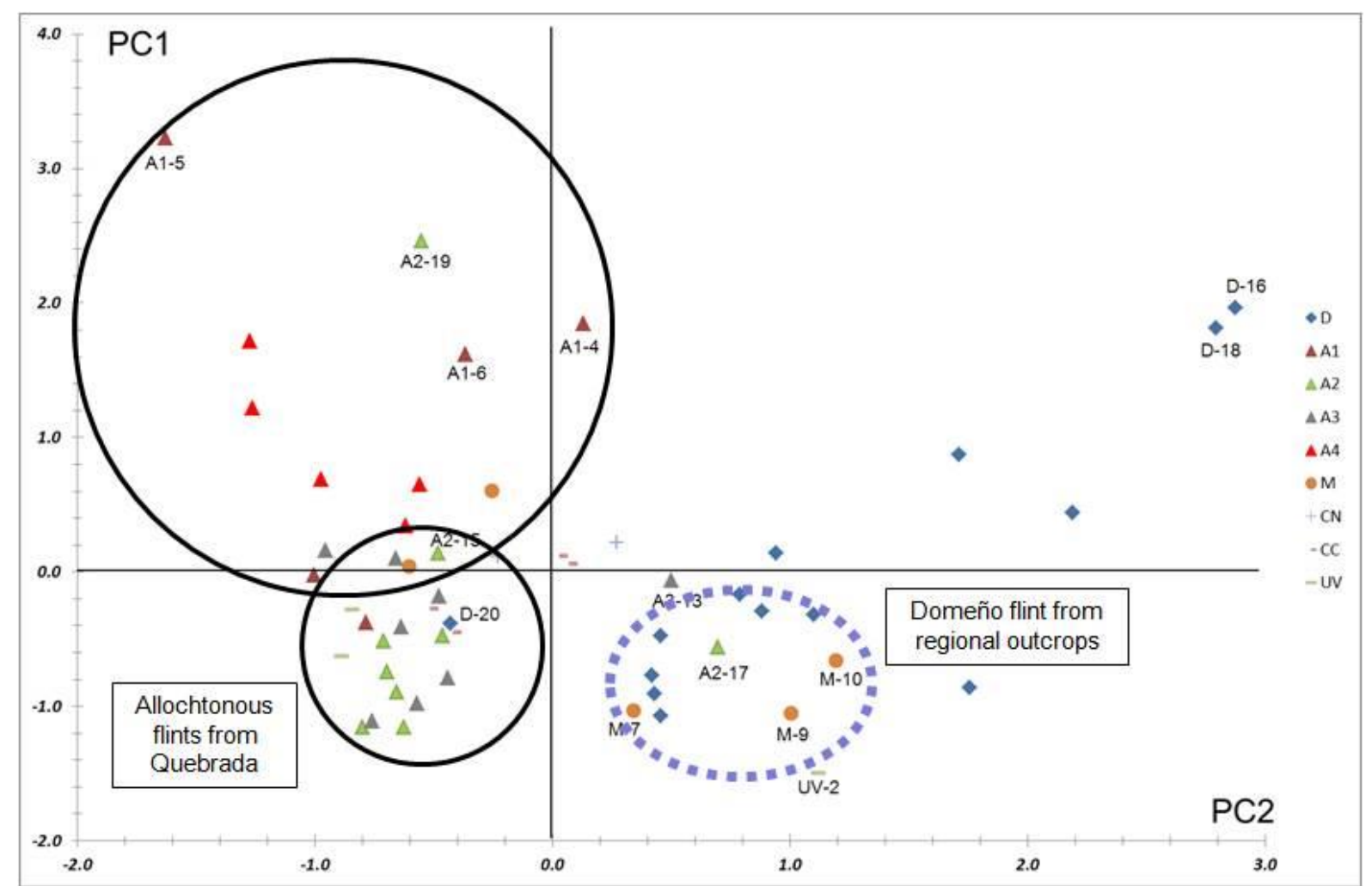

Figure 7. Principal components 1 and 2 derived from PCA of the allochthonous flints (XRF data).

The separateness of the allochthonous types and their classification into different groups are also clearly supported by the analyses (Figure 7). Based on macroscopic criteria that have yet to be corroborated, we have assigned to these types flints from other sites of the Valencian Palaeolithic located at considerable distances from Quebrada. Although such results are preliminary, they suggest that Type 1 is present in the Middle Palaeolithic of Cova de la Petxina $(100 \mathrm{~km})$ and Rambla de los Morenos $(30 \mathrm{~km})$, and in the Upper Palaeolithic of Cova del Parpalló $(100 \mathrm{~km})$. As to Type 2, we have identified it in (a) the Middle and Lower Palaeolithic of San Luís (40 km), Rambla de los Morenos (30 km), Barranco de Carcalín (40 $\mathrm{km})$, Las Fuentes $(70 \mathrm{~km})$, Cova de la Petxina $(100 \mathrm{~km})$, Cova del Bolomor $(100 \mathrm{~km})$ and Cova Negra $(100 \mathrm{~km}),(\mathrm{b})$ the Upper Palaeolithic of Cova de les Malladetes $(100 \mathrm{~km})$, Volcán del Faro $(90 \mathrm{~km})$ and Abric de la Senda Vedada $(80 \mathrm{~km})$, and (c) the Epipalaeolithic of Cueva de la Cocina $(50 \mathrm{~km})$; this type may also be represented in the Middle Palaeolithic of Abric del Pastor and the natural flint outcrops from La Serreta, in the Alcoi area (Molina et al. 2010), indicating that it circulated widely. Type 3 has been documented at Cova del Parpalló $(100 \mathrm{~km})$, Cova de les Malladetes $(100 \mathrm{~km})$, Cova de les Cendres $(150 \mathrm{~km})$, Balma de la Roureda $(90 \mathrm{~km})$ and Sant Joan de Nepomucè $(100 \mathrm{~km})$. For Type 4, no secure identification of its presence at other sites can be made with current data.

Twenty-one samples were analyzed by XRD: seven of Domeño-type, two of allochthonous Type 1, four of allochthonous Type 2, four of allochthonous Type 3 and four 
archaeological samples from Cova de les Cendres. They show quartz and calcite as the main crystalline phases with occasional presence of pyrolusite, moganite, silicates and oxides. Comparison is made difficult due to the dominance of quartz in all of them. However, we noted that the size of quartz crystals, estimated by means of the equation of Scherrer (based on the resolution of the quartz diffraction patterns around the peak at $2 \theta 68^{\circ}$ ), is larger among the local Domeño-type samples than among those catalogued as allochthonous. This supports the separateness of the Domeño type indicated by the XRF analysis.

\section{Conclusions}

Our study is still in an initial stage and the results obtained so far are preliminary and in need of corroboration and augmentation by additional analysis and field work. Yet, it is already possible to derive from them a suggestion of significant levels of mobility across extended territories, including the transit areas and natural corridors of the Valencian region (Aura et al. 1993) that connect interior and coast via the Turia, Plana de Utiel and Magro corridors. These rivers all converge to the large Valencia plain, allowing for movement towards the North (Quebrada) as much as to the South, namely to the site clusters of Gandia and Xàtiva (Cova Negra, Cova Foradada, Cova del Gat and Cova de la Petxina) or Alcoi (Cova Beneito, Abric del Pastor and El Salt) (See Figure 1).

At present, we favor the explanation that the spatial distribution pattern observed reflects the circulation of individual groups across subsistence territories of rather large size. Alternatively, it could reflect the circulation of raw materials through long distance exchange networks. Additional work is ongoing or in preparation with the aim of testing these alternatives. The planned work includes extended survey to locate as yet unknown sources and the analysis of more samples from a wider range of sites from different parts of the region and from different periods of its Prehistory.

\section{Acknowledgements}

Research for the present paper has been supported by the following projects: "El final del Paleolítico medio y el Paleolítico superior en la región central del Mediterráneo ibérico" (FFI 2008-01200/FISO), "La conducta de los neandertales: una aproximación a partir del registro arqueológico del Abrigo de la Quebrada (Chelva, Valencia)" (HAR 2008-04273-E/HIST), "Paleolítico medio final y Paleolítico superior inicial en la región central mediterránea (Valencia y Murcia)" (HAR2011-24878) and "Mas allá de la Historia: los inicios del poblamiento paleolítico valenciano" (PROMETEOII/2013/016). Finally, the authors would like to thank Jorgelina Carballo for her help in carrying out the EDXRF analyses.

\section{References}

Aura, E., Fernández, J. \& Fumanal, Mª P. 1993, Medio físico y corredores naturales: notas sobre el poblamiento paleolítico del País valenciano. Recerques del Museu d'Alcoi, 11: 89-107. (in Spanish) ("Physical medium and natural corridors: some notes on the Palaeolithic settlement in valencian country").

Eixea, A., Villaverde, V. \& Zilhão, J. 2011, Aproximación al aprovisionamiento de materias primas líticas en el yacimiento del Paleolítico medio del Abrigo de la Quebrada (Chelva, Valencia). Trabajos de Prehistoria, 68(1): 65-78. (in Spanish) (“An approach to lithic raw material procurement at the middle Palaeolithic site Abrigo de la Quebrada (Chelva, Valencia)") doi:10.3989/tp.2011.11059 
Eixea, A., Villaverde, V., Zilhão, J., Sanchis, A., Morales, J., Real, C. \& Bergadà, M. 2012, El nivel IV de Abrigo de la Quebrada (Chelva, Valencia). Análisis microespacial y valoración del uso del espacio en los yacimientos del Paleolítico medio valenciano. Mainake, 33(2011-2012): 127-158. (in Spanish) (“Abrigo de la Quebrada (Chelva, Valencia) level IV. Micro-spatial analysis and assessment of intra-site spatial variability in the Middle Palaeolithic sites of Valencia")

Faus, E. 2009, Apuntes sobre afloramientos y áreas con presencia de materias primas silíceas localizadas en las comarcas del Comtat y La Marina Alta (Alacant). Alberri, 19 (20082009): 9-38. (in Spanish) ("Notes on outcrops and areas with siliceous raw materials located in the Comtat and La Marina Alta areas (Alacant)")

García-Carrillo, A., Cacho, C. \& Ripoll, S. 1991, Sobre la selección del sílex y su aprovisionamiento en el Tossal de la Roca (Vall d'Alcalà, Alicante). Espacio, Tiempo y Forma, serie 1, Prehistoria y Arqueología, 4: 15-36. (in Spanish) ("On flint procurement and selection at Tossal de la Roca (Vall d'Alcalà, Alicante)") doi:10.5944/etf i.4.4543

Gómez, J. \& Fernández, S. 2004, Las unidades litoestratigráficas del Jurásico Medio de la Cordillera Ibérica). Geogaceta, 35: 91-94. (in Spanish) ("The Middle Jurassic lithostratigraphic units from the Iberian Range")

IGME (Instituto Geológico y Minero de España) 1972, Hoja (sheet) 666, 27-26, Chelva. E. 1:50.000. Segunda serie. Primera edición. Servicio de Publicaciones, Ministerio de Industria, Madrid. (in Spanish) (“Spanish Geological Survey, Map sheet 666, 27-26”)

Masson, A. 1979, Recherches sur la provenance des silex préhistoriques. Méthode d'étude. Études Préhistoriques, 15: 29-40 (in French) ("Investigation of the provenance of Prehistoric flint")

Masson, A. 1980, Pétroarchéologie des roches siliceuses. Intérêt en Préhistoire, Unpublished $\mathrm{PhD}$ dissertation. Université Claude Bérnard-Lyon I, Lyon, 101 p. (in French) ("Petroarchaeology of siliceous rocks. Its interest in Prehistory")

Menargues, J. 2005, La explotación de las rocas locales en los yacimientos paleolíticos de la Ratlla del Bubo (Crevillent, Alicante) y la Cova de les Cendres (Teulada, Alicante). In: Geoarqueología y Patrimonio en la Península Ibérica y el entorno mediterráneo, (Santonja, M., Pérez-González, A. \& M. J. Machado, M. J., Eds.) Adema Patrimonio. Editorial Almazán, Soria: p. 413-424. (in Spanish) ("The exploitation of local rocks in the Palaeolithic sites Ratlla del Bubo (Crevillent, Alicante) and Cova de les Cendres (Teulada, Alicante)")

Molina, F. J., Tarriño, A., Galván, B., \& Hernández, C. 2010, Áreas de aprovisionamiento de sílex en el Paleolítico medio en torno al Abric del Pastor (Alcoi, Alicante). Recerques del Museu d'Alcoi, 19: 65-80. (in Spanish) ("Flint supplying areas dated during the Middle Palaeolithic around the Abric del Pastor (Alcoy, Alicante, Spain), through the macroscopic study of the Brotons Collection")

Moriel, A. 1985, Aplicación de una metodología de estudio de las funciones de las raederas de Cova Negra (Xàtiva, Valencia). Cuadernos de Prehistoria y Arqueología Castellonenses, 11: 17-86. (in Spanish) ("Applying a methodology for the functional study of side scrapers from Cova Negra (Xàtiva, Valencia)")

Schmich, S. \& Wilkens, B. 2006, Non-destructive Identification and Characterization of Lithics from the Polop Alto: A Preliminary Assessment Using Proton Induced X-ray 
Emission (PIXE). In: El Abric de la Falguera (Alcoi, Alacant), (García, O. \& Aura, J. A., Eds.), Diputación Provincial de Alicante, Alicante: p. 164-170.

Tiffagom, M. 2006, De la Pierre à l'Homme. Essai sur une paléoanthropologie solutréenne, Eraul. Université de Liège, Service de Prehistoire, Liège, 290 p. (in French) ("From Stone to Man. An essay on Solutrean palaeoanthropology")

Villaverde, V.; Eixea, A. \& Zilhão, J. 2008, Aproximación a la industria lítica del Abrigo de la Quebrada (Chelva, Valencia). Treballs d'Arqueologia, 14: 213-228. (in Spanish)("Lithic industry of Abrigo de la Quebrada (Chelva, Valencia)")

Villaverde, V., Roman, D., Martínez Valle, R., Pérez Ripoll, M., Badal, E., Bergadà, M., Guillem, P. M. \& Tormo, C. 2010, El Paleolítico superior en el País Valenciano: Novedades y perspectivas. In: Jornadas Internacionales sobre el Paleolítico superior peninsular. Novedades del Siglo XXI, (Mangado, X., Ed.), Monografies del SERP Vol. 8, Barcelona: p. 85-113. (in Spanish) ("The Upper Palaeolithic in the Valencian Country. Progress and Prospects") 
